\title{
VARIABILITY AND COVARIABILITY OF AGRONOMIC CHARACTERISTICS IN 14 KENAF GENOTYPES
}

\author{
AFAF E.A. ZAHANA and AMANY M.M. EL-REFAIE
}

Field Crops Res .Inst., ARC, Giza, Egypt

(Manuscript received 29 July 2012)

\begin{abstract}
A field experiment was conducted during 2009, 2010 and 2011 seasons at Ismailia Agricultural Research station, Ismailia Governorate, Egypt, to study the variability and covariability of 14 kenaf genotypes including green stalk yield, fiber yield and their related characters. The experimental design was randomized complete block with three replications per each of the three environments (seasons ). Mean square values showed highly significant differences among genotypes (G) and genotypes $x$ environments (E) interaction for green stalk yield and its components viz.: plant height, technical stem length, fiber yield and fiber percentage as well as seed yield and fruiting zone length. Variances due to differences among genotypes (G) were higher than those due to the interaction ( $G \times E)$ for all characters studied except fiber yield/fed. These results indicated that most of the variability for these traits were mainly controlled by genetic factors less influenced by environmental factors. This means that the improvement of these traits could be achieved by selection. Heritability values (Hb.s.) in broad sense were high for seed weight/plant followed by plant height and technical stem length. Also, the observed narrow range between phenotypic (PCV) and genotypic (GCV) coefficients of variability, which gave almost similar values of PCV and GCV for seed weight/plant were mainly due to genetic differences as evidenced from the very high heritability. Also, fiber weight per plant, plant height and technical stem length showed similar results, indicating the possibility of using these yield components in selection index giving more weight for plant height and technical stem length for improving green weight/plant. Kenaf cultivars, S.105/2 and S.96/20 proved maximum (first or second ranking for mean performance) for most characters studied. While, the first ranking was recorded by S.96/20 for seed yield per fed as well as S.116 for seed weight per plant and S.8 for fruiting zone length. Therefore, the previous mentioned genotypes specially S.105/2 may be released as a commercial cultivar and/or to be incorporated as breeding stocks in kenaf breeding program aiming at producing high yielding lines. Phenotypic and genotypic correlation coefficients among green stalk weight, fiber weight per plant and their related characters of 14 kenaf genotypes averaged over the three environments, indicated that, plant height and technical
\end{abstract}


stem length are the major components contributing to green stalk weight per plant. Therefore, selection for these traits may improve green stalk weight per plant and in turn fiber yield in kenaf.

\section{INTRODUCTION}

In Egypt, Kenaf (Hibiscus cannabinus L.) is cultivated to produce bast fiber, which is used alone or mixed with jute fiber to manufacture bags, twine, ropes and other products. It would be expected as a raw material to be an alternative to wood fiber in pulp and paper industry. Moreover, kenaf seeds contain similar oil to that extracted from cotton seeds but free from gossypol (poisonous material) as edible for human.

Kenaf will grow well and produce high fiber yield when grown on an extremely wide range of soils. The principal requirement is that the soils possess good drainage, although it will tolerate flooding in the last stages of growth. It can be planted on marginal land. Therefore, it is suitable to Egyptian agriculture for marginal and submarginal soils (such as sandy soil). Many investigators studied the differences between kenaf genotypes (e.g.,Osman and Momtaz,1982, El-Shimy et al.,1990 and Abd El-Dayem, 2001). On the other hand, the estimation of some genetic parameters in kenaf is limited. Subramanyam et al., (1995) studying the heritability in eight kenaf hybrids found that, fiber weight per plant and green plant weight showed high heritability, indicating that selection in early generations would be effective. Abd ElDayem (2001) found that heritability ratios in broad sense were high in all traits studied.

Before the beginning of any breeding program, thorough knowledge of the nature and magnitude of genetic variability and the extent of association between yield and yield components are essential. Similarly, phenotypic and genotypic variance as well as heritability estimates for fiber yield and its related characters and associations between fiber yield and other related characters are considered basic information for designing a successful breeding program to improve fiber yield in kenaf. According to Burton (1952) the genotypic coefficient of variability together with heritability estimate would give the best indication of the amount of genetic advance to be expected from selection.

Therefore, the main objectives of the present study were to (1) quantitatively assess the pattern of genotypes variation, the nature of association between key traits of green stalk yield and fiber yield, (2) estimate phenotypic and genotypic variance deriving statistics, unbiased by GE variance such as heritability and genetic coefficient of variation and use these parameters to provide information essential for population 
identification as well as to aid in planning more efficient improvement kenaf program by selection.

\section{MATERIALS AND METHODS}

The materials used for the present study consisted of 14 kenaf genotypes (one local variety, 12 advanced lines and one introduction). The classification and pedigree of the 14 genotypes used are partially described in Table1.

Table 1. Pedigree of the 14 kenaf genotypes under study, origin and year released

\begin{tabular}{|c|c|c|c|}
\hline Genotypes & Pedigree & Origin & Year released ${ }^{\mathrm{t}}$ \\
\hline 1- Giza 3 & Local cultivar & Land race & 1961 \\
\hline 2-S. 8 & Selected from H.106 (G.5 x 77/68-1) & Advanced line & 1993 \\
\hline 3- S.105/2 & Giza 5 x S.87/68-1 & " " " " & 1994 \\
\hline 4- S.96/20 & Giza $3 \times 17 / 64-2$ & " " " " & 2002 \\
\hline $5-\mathrm{S} .108 / 9$ & Giza 3 x S.127/130 & " " " " & 1996 \\
\hline 6- S.98/205 & S.77/68/1 x S.87/68/1 & " " " " & 1992 \\
\hline 7- S.112 & H.27/127 x H.27/130 & " " " " & 1994 \\
\hline 8- S.119 & Selected from H.119 (G.4 x 16/63-2) & " " " " & 2000 \\
\hline 9- S. 114 & S. $16 / 63 / 2 \times S .29 / 145$ & " " " " & 1993 \\
\hline 10-New Indian & Selected from I. New Indian & India & 1996 \\
\hline $11-\mathrm{S} .38$ & Giza 3 x 4/59-27 & Advanced line & 1976 \\
\hline $12-\mathrm{S} .113$ & S. $16 / 63 \times \mathrm{S} .4 / 59 / 3$ & " " " " & 1990 \\
\hline $13-\mathrm{S} .116$ & $S .4 / 59 \times S .29 / 1451$ & " " " " & 1998 \\
\hline $14-S .45 / 29$ & $\mathrm{~S} .80 / 68 / 1 \times \mathrm{S} .4 / 59 / 26$ & " " " " & 1977 \\
\hline
\end{tabular}

\section{${ }^{t}$ Year released, selected or introduced}

These 14 genotypes were evaluated in three consecutive seasons (2009 to 2011) at Ismailia Agricultural Research Station, Ismailia Governorate (Sandy soil, $\mathrm{pH}=7.55$ ). The experimental design was randomized complete block with three replications per each of the three environments (seasons ). Sowing date was the first week of May in all seasons. The plot size was $3 \mathrm{~m}$ long and 2 meters wide (1/700 fed) and consisted of 4 rows, $50 \mathrm{~cm}$ apart and the distance between hills was $20 \mathrm{~cm}$. Thinning to two plants per hill was performed four weeks after sowing. The recommended cultural practices for kenaf production were at that area applied. At maturity stage, ten random guarded plants from each plot were taken to score the following traits: 
(1) Green stalk yield (ton)/fed, (2) Fiber yield ( $\mathrm{Kg}$ )/fed (these two characters were calculated and converted from yield per plot), (3) Fiber percentage $=$ (fiber weight per plant x $100 \div$ green weight per plant), (4) Green weight (g)/plant, as weight in grams of kenaf stalk plant after 48 hours from harvesting, (5) Fiber weight $(\mathrm{g}) /$ plant, as the weight in grams of the air-dried fibers extracted from retted green stalk of kenaf plant, (6) Plant height $(\mathrm{m})$, measured as the distance from the two cotyledonary nodes up to uppermost capsule, (7) Technical stem length ( $m)$, measured as the distance from the two cotyledonary nodes to the first apical branch, (8) Seed yield $(\mathrm{Kg}) /$ fed (calculated from yield per plot), (9) Seed weight ( $\mathrm{g}$ )/plant and (10) Fruiting zone length $(m)$, measured as the distance from the first apical branch to uppermost capsule.

\section{Statistical analysis}

Plot means were used for statistical analysis. The data obtained for each season were subjected to analysis of variance (Gomez and Gomez,1984) and were combined after homogeneity test (Bartlett test) proved insignificant error terms. Genotypic $\left(V_{g}\right)$, environmental $\left(V_{e}\right)$, their interaction $\left(V_{g e}\right)$ and phenotypic $\left(V_{p}\right)$ variances, as well as phenotypic (PCV) and genotypic (GCV) coefficients of variation, heritability in broad sense $\left(H_{\text {b.s. }}\right)$ and phenotypic $\left(r_{p}\right)$ and genotypic $\left(r_{g}\right)$ correlation coefficients were calculated according to Johnson et al., (1955) as follows:

\begin{tabular}{|l|l|l|l|l|}
\hline SOV & df & MS & Expected MS & E. Cov. Of cross product \\
\hline Environment (season) & 2 & & & \\
Rep./Environment & 6 & & & \\
Genotype (G) & 13 & $M_{1}$ & $\sigma^{2} e+3 \sigma^{2} g y+9 \sigma^{2} g$ & $\sigma_{\mathrm{e} 12}+3 \sigma_{g y} 12+9 \sigma_{g} 12$ \\
G x Environment & 26 & $M_{2}$ & $\sigma^{2} e+3 \sigma^{2} g y$ & $\sigma_{\mathrm{e} 12}+3 \sigma_{g y} 12$ \\
Error & 78 & $M_{3}$ & $\sigma^{2}$ & $\sigma_{\mathrm{e} 12}$ \\
\hline
\end{tabular}

Where (1), $\sigma^{2} e, \sigma^{2}$ gy and $\sigma^{2} g=$ environmental, genotypic $x$ environmental and genotypic variances, respectively,

(2) $\sigma_{e} 12, \sigma_{g y} 12$ and $\sigma_{g 12}$ are the corresponding covariance components for the characters, 1 and 2 .

For the above table the following estimates were calculated:

$\sigma_{p}^{2}=$ phenotypic variance among the variety means $=M 1 /(2 * 4)$

$\sigma^{2} \mathrm{~g}=$ phenotypic variance among the variety means $=(M 1-M 2) / \mathrm{rn}$

$\sigma^{2}$ ge $=$ Genotypic $X$ environmental variance $=M 2-M 3 / r$

$\mathrm{r}_{12 \mathrm{p}}=$ phenotypic correlation between characters 1 and $2=\sigma_{12 \mathrm{p}} /\left(\sigma_{1 \mathrm{p}} * \sigma_{2 \mathrm{p}}\right)$

$r_{12 g}=$ genotypic correlation $=\sigma_{12 g} /\left(\sigma_{1 g} * \sigma_{2 g}\right)$ 


\section{RESULTS AND DISCUSSION}

\section{1-Variability and genetic parameters}

Mean square from the combined analysis of variance over environments (seasons) for ten characters of kenaf presented in Table (2) showed high significant differences among genotypes for green stalk yield and its components viz.: plant height, technical stem length, fiber yield and fiber percentage as well as seed yield and fruiting zone length. This is expected because the materials under study consisted of different kenaf types which, as illustrated in Table (1), differed in their origin, pedigree and consequently genetic background. Such variability among different kenaf genotypes in green stalk yield and its components was also reported by $\mathrm{Abd} \mathrm{El-}$ Dayem (2001), Abo-Kaied (2007) and Abo-Kaied and Abuo Zaid (2008).

High significant differences were also observed for all ten characters studied due to genotype $x$ environment interaction indicating that genotypes had considerable different responses to environmental influences (Table 2). It appears, from these results, that the genotypes under study possess great genetic variability sufficient to provide substantial amounts of improvement through selecting superior genotypes. The ratio between the two variances ( $G$ and $G \times E$ interaction) was greater for all ten characters studied except for fiber yield/fed, indicating that most of the variability were mainly controlled by genetic factors. This means that improvement of these traits could be achieved by direct selection. The effectiveness of selection depends on the variability present in a germplasm and the extent to which it is heritable (Miller and Rowling, 1967).

Estimates of the variance components among 14 kenaf genotypes for ten characters are shown in Table (2). The genotype $x$ year variance $\left(\sigma^{2} g e\right)$ was less than the genotypic variance $\left(\sigma^{2} g\right)$ for plant height, technical stem length and seed weight/plant. These results supported the previously mentioned conclusion, that the biased introduced by year was small, concerning beneficial selection for most yield components, specially seed weight, plant height and technical stem length. Heritability values in broad sense (Hb.s.) were high for seed weight/plant $(90.27 \%)$ followed by plant height $(86.28 \%)$ and technical stem length $(86.03 \%)$ (Table 3). Also, the observed narrow range between phenotypic (PCV) and genotypic (GCV) coefficients of variability, which gave close values of PCV $(21.15 \%)$ and GCV $(20.10 \%)$ for seed weight/plant was mainly due to genetic differences as evidenced from the very high heritability. Also, fiber weight/plant, plant height and technical stem length showed similar results, indicating possibility of using these yield components in selection index giving more weight for plant height and technical stem length for improving green weight/plant. These results are in harmony with those reported by others (Osman and Momtaz,1982, El-Kady and El-Sweify,1995, Abd El-Dayem, 2001, AboKaied, 2007 and Abo-Kaied and Abuo Zaid, 2008). On the other hand, green weight/plant, fiber percentage and fruiting zone length exhibited low or moderate heritability values in addition to wide difference between phenotypic (PCV) and genotypic (GCV) coefficients of variability. 


\section{Mean performance}

Mean performance and ranking of means for green stalk yield, fiber yield and other related characters for the 14 kenaf genotypes averaged over three environments are presented in Table (4). S.105/2 followed by S.113 and commercial variety Giza 3 showed high mean performance (high ranking) for green stalk yield/fed (12.184, 10.815 and 10.665 t, respectively). Also, S.105/2 and S.113 mean performance exhibited high ranking for fiber yield/fed (120.201 and $95.086 \mathrm{~kg}$, respectively). Also, S.105/2 followed S.96/20 exhibited high mean performance for fiber percentage (9.877 and $9.742 \%$, respectively). Whereas, S.105/2 followed by Giza 3 recoded high mean performance for both green stalk yield/plant (393.911 and $270.044 \mathrm{~g})$ and fiber weight/plant (38.857 and $23.470 \mathrm{~g})$. S.105/2 recorded high ranking for both plant height $(2.428 \mathrm{~m})$ and technical stem length $(1.737 \mathrm{~m})$ which are considered two important components of green stalk weight/plant. While, the first ranking was recorded by S.96/20 for seed yield/fed ( $81.804 \mathrm{~kg} / \mathrm{fed})$ as well as S.116 for seed weight/plant $(1.408 \mathrm{~g})$ and $\mathrm{S} .8$ for fruiting zone length $(0.717 \mathrm{~m})$. Results indicated that S.105/2 and S.96/20 proved maximum (first or second rank for mean performance) for most characters studied. Therefore, the previous mentioned genotypes specially S.105/2 may be released as commercial cultivar and/or to be incorporated as breeding stocks in kenaf breeding program aiming at producing high yielding lines.

\section{2- Covariability}

Phenotypic $\left(r_{p}\right)$ and genotypic $\left(r_{g}\right)$ correlation coefficients among green stalk weight, fiber weight/ plant and their related characters of 14 kenaf genotypes averaged over three environments are shown in Table (5). Green stalk weight/plant exhibited significant positive correlation with each of fiber weight/plant, plant height and fruiting zone length. Also, fiber weight/plant exhibited significant positive correlation with each of plant height, technical stem length, seed weight/plant and fruiting zone length. These results, indicated that maximization of fiber weight/plant may be obtained via selection for previous traits, specially plant height and technical stem length, where there was significant positive association between fiber percentage and fiber weight/plant. Moreover, significant association was obtained between plant height with each of technical stem length, seed weight/plant and fruiting zone length. Seed weight/plant was highly significant positive correlated with fruiting zone length. These results indicated that plant height and technical stem length are the main components for fiber weight/plant. These results are in agreement with those obtained by Mourad et al.(1987), El-Shimy et al. (1990), Bunpromma (1992), Abo-Kaied (2007) and Abo-Kaied and Abuo Zaid (2008).

In general, it could be concluded that plant height and technical stem length are the major components contributing to green stalk weight/plant. Therefore, selection for these traits will improve fiber weight/plant in kenaf crop. 
Table 2. Genotype, environment and genotype $\mathrm{x}$ environment interaction mean squares from the combined analysis of variance over three environments for ten characters of kenaf.

\begin{tabular}{|c|c|c|c|c|c|}
\hline Character & 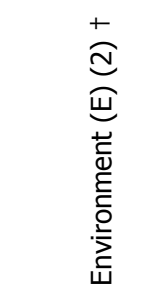 & 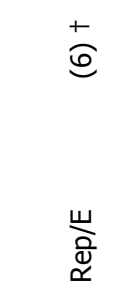 & 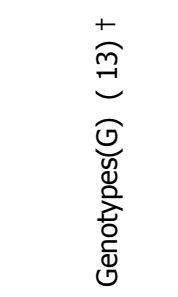 & 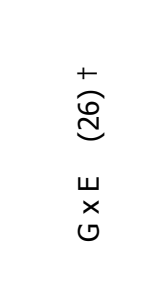 & 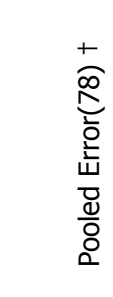 \\
\hline Green stalk yield (ton)/fed & $48.972 \quad * *$ & 0.882 & $9.735 \quad * *$ & $2.688^{* *}$ & 0.443 \\
\hline Fiber yield $(\mathrm{kg}) /$ fed & $3117.723 * *$ & 76.199 & $181.257 * *$ & $974.520 * *$ & 54.288 \\
\hline Fiber percentage (\%) & 1.477 & 0.026 & $1.172 * *$ & $0.787 * *$ & 0.404 \\
\hline Green weight (g) / plant & $29747.62 * *$ & 720.399* & $25327.93 * *$ & $12686.62 * *$ & 289.142 \\
\hline Fiber weight $(\mathrm{g}) /$ plant & $190.039 * *$ & 5.428 & $243.866 * *$ & $39.657 * *$ & 3.410 \\
\hline Plant height $(\mathrm{m})$ & $1.635 \quad * *$ & $0.012 * *$ & 0.593 & $0.081 * *$ & 0.003 \\
\hline Technical stem length $(\mathrm{m})$ & 1.008 & 0.001 & 0.262 & $0.037 * *$ & 0.001 \\
\hline Seed yield $(\mathrm{kg}) / \mathrm{fed}$ & $1856.986 * *$ & 34.826 & $1565.487 * *$ & $107.793 * *$ & 34.362 \\
\hline Seed weight $(\mathrm{g}) /$ plant & 2.329 & 0.048 & $5.028 * *$ & $0.489 * *$ & 0.054 \\
\hline Fruiting zone length $(\mathrm{m})$ & $0.080 \quad * *$ & 0.008 & $0.124 * *$ & $0.039 * *$ & 0.004 \\
\hline
\end{tabular}

$*, * *=$ Indicate significant and highly significant at 0.05 and 0.01 , respectively.

$\dagger=$ Values between parenthesis designate the corresponding degrees of freedom 
Table 3. Variance component estimates from combined ANOVA, phenotypic (PCV) and genotypic (GCV) coefficients of variability and broad sense heritability $(\mathrm{H})$ for green weight, seed weight/plant and their components of kenaf over three environments (three successive seasons).

\begin{tabular}{|l|l|l|l|l|l|l|l|}
\hline \multicolumn{1}{|c|}{ Character } & $\square_{\mathrm{ph}}^{2}$ & $\square_{g}^{2}$ & $\square_{\mathrm{ge}}^{2}$ & $\square_{\mathrm{e}}^{\mathrm{g}_{\mathrm{g}}}$ & \multicolumn{1}{c|}{$\mathrm{H}^{2}$} & PCV\% & GCV\% \\
\hline Green weight (g) / plant & 1407.11 & 702.295 & 4132.491 & 289.142 & 49.91 & 16.04 & 11.34 \\
\hline Fiber percentage (\%) & 0.065 & 0.021 & 0.128 & 0.404 & 32.89 & 2.93 & 1.68 \\
\hline Fiber weight (g) / plant & 13.548 & 11.345 & 12.082 & 3.410 & 83.74 & 17.94 & 16.42 \\
\hline Plant height (m) & 0.033 & 0.028 & 0.026 & 0.003 & 86.28 & 9.92 & 9.22 \\
\hline Technical stem length(m) & 0.015 & 0.013 & 0.012 & 0.001 & 86.03 & 8.39 & 7.79 \\
\hline Seed weight (g) / plant & 0.279 & 0.252 & 0.145 & 0.054 & 90.27 & 21.15 & 20.10 \\
\hline Fruiting zone length (m) & 0.007 & 0.005 & 0.012 & 0.004 & 68.20 & 21.13 & 17.45 \\
\hline
\end{tabular}

$\square_{\mathrm{ph},}^{2} \square_{\mathrm{g}, \mathrm{r}}^{2} \square_{\mathrm{ge},}^{2} \square_{\mathrm{e}}^{\square}$ are the variance attributed to ,phenotype, genotype , genotype $\mathrm{x}$ environment interaction and plot error, respectively.

Table 4. Mean yield and rank for ten characters of 14 kenaf genotypes over three environments (three successive seasons).

\begin{tabular}{|c|c|c|c|c|c|c|c|c|c|c|}
\hline Genotypes & 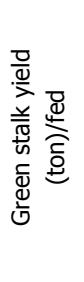 & $\begin{array}{l}\text { 营 } \\
\stackrel{2}{\simeq}\end{array}$ & 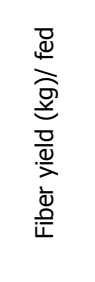 & 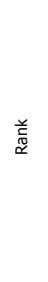 & 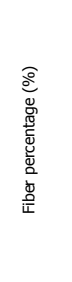 & $\begin{array}{l}\text { 总 } \\
\text { 戛 }\end{array}$ & 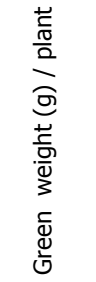 & $\begin{array}{l}\text { 荡 } \\
\text { 足 }\end{array}$ & 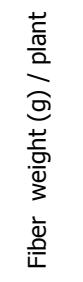 & $\begin{array}{l}\text { 兰 } \\
\text { 足 }\end{array}$ \\
\hline 1- Giza 3 & 10.665 & 3 & 92.683 & 4 & 8.693 & 6 & 270.044 & 2 & 23.470 & 2 \\
\hline 2-S. 8 & 10.522 & 4 & 91.181 & 5 & 8.690 & 7 & 249.078 & 4 & 21.542 & 5 \\
\hline 3- S.105/2 & 12.184 & 1 & 120.201 & 1 & 9.877 & 1 & 393.911 & 1 & 38.857 & 1 \\
\hline 4- $5.96 / 20$ & 9.691 & 6 & 93.972 & 3 & 9.742 & 2 & 235.144 & 6 & 22.880 & 3 \\
\hline 5- S.108/9 & 8.101 & 12 & 66.122 & 13 & 8.182 & 12 & 197.422 & 12 & 16.109 & 13 \\
\hline 6- S.98/205 & 7.367 & 14 & 63.488 & 14 & 8.658 & 8 & 177.133 & 14 & 15.240 & 14 \\
\hline 7- 5.112 & 9.032 & 9 & 81.721 & 7 & 9.044 & 3 & 219.033 & 7 & 19.827 & 7 \\
\hline 8- S.119 & 9.314 & 7 & 77.969 & 9 & 8.364 & 11 & 214.033 & 9 & 17.933 & 9 \\
\hline 9-S. 114 & 8.055 & 13 & 67.437 & 12 & 8.382 & 10 & 193.256 & 13 & 16.160 & 12 \\
\hline 10-New Indian & 9.238 & 8 & 80.682 & 8 & 8.753 & 5 & 215.422 & 8 & 18.838 & 8 \\
\hline $11-5.38$ & 8.774 & 11 & 70.906 & 11 & 8.082 & 13 & 201.822 & 11 & 16.309 & 13 \\
\hline $12-\mathrm{S} .113$ & 10.815 & 2 & 95.086 & 2 & 8.796 & 4 & 241.444 & 5 & 21.210 & 6 \\
\hline $13-S .116$ & 10.113 & 5 & 87.108 & 6 & 8.642 & 9 & 257.178 & 3 & 22.132 & 4 \\
\hline $14-5.45 / 29$ & 8.935 & 10 & 71.511 & 10 & 8.021 & 14 & 208.344 & 10 & 16.686 & 10 \\
\hline General mean & 9.486 & & 82.862 & & 8.709 & & 233.805 & & 20.514 & \\
\hline $\operatorname{LSD}_{0.05}$ & 0.762 & & 11.912 & & 0.744 & & 3.849 & & 1.268 & \\
\hline c.V. \% & 7.02 & & 8.89 & & 7.30 & & 7.27 & & 9.00 & \\
\hline
\end{tabular}


Table 4. (Cont.'d)

\begin{tabular}{|c|c|c|c|c|c|c|c|c|c|c|}
\hline Genotypes & 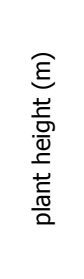 & 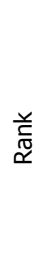 & 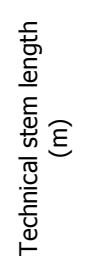 & 兹 & 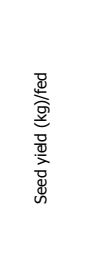 & 培 & 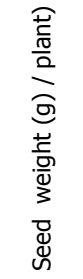 & 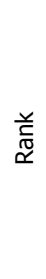 & 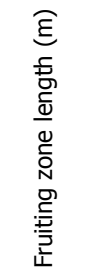 & 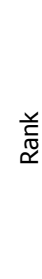 \\
\hline 1- Giza 3 & 1.914 & 6 & 1.540 & 5 & 70.680 & 5 & 2.660 & 7 & 0.374 & 5 \\
\hline 2-S. 8 & 2.176 & 2 & 1.459 & 7 & 57.949 & 9 & 2.276 & 6 & 0.717 & 1 \\
\hline 3- S.105/2 & 2.428 & 1 & 1.737 & 1 & 72.492 & 4 & 4.332 & $\begin{array}{l}1 \\
4\end{array}$ & 0.694 & 2 \\
\hline 4- S.96/20 & 1.960 & 5 & 1.630 & 2 & 81.804 & 1 & 3.411 & $\begin{array}{l}1 \\
3\end{array}$ & 0.327 & 11 \\
\hline 5- S.108/9 & 1.662 & $\begin{array}{l}1 \\
1\end{array}$ & 1.318 & $\begin{array}{l}1 \\
1\end{array}$ & 50.917 & $\begin{array}{l}1 \\
0\end{array}$ & 1.990 & 5 & 0.347 & 8 \\
\hline 6- S.98/205 & 1.222 & $\begin{array}{l}1 \\
4\end{array}$ & 0.996 & $\begin{array}{l}1 \\
4\end{array}$ & 42.839 & $\begin{array}{l}1 \\
3\end{array}$ & 1.512 & 2 & 0.224 & 13 \\
\hline 7- S.112 & 1.987 & 3 & 1.594 & 4 & 65.103 & 8 & 2.897 & $\begin{array}{l}1 \\
1\end{array}$ & 0.391 & 4 \\
\hline 8- S.119 & 1.592 & $\begin{array}{l}1 \\
2\end{array}$ & 1.252 & $\begin{array}{l}1 \\
3\end{array}$ & 49.869 & $\begin{array}{l}1 \\
1 \\
\end{array}$ & 1.587 & 3 & 0.341 & 9 \\
\hline 9- S. 114 & 1.591 & $\begin{array}{l}2 \\
1 \\
3\end{array}$ & 1.373 & $\begin{array}{l}0 \\
1 \\
0\end{array}$ & 68.428 & 7 & 2.686 & 8 & 0.219 & 14 \\
\hline 10-New Indian & 1.870 & 7 & 1.534 & 6 & 81.432 & 2 & 2.720 & 9 & 0.337 & 10 \\
\hline $11-\mathrm{S} .38$ & 1.726 & 9 & 1.376 & 9 & 47.399 & $\begin{array}{l}1 \\
2\end{array}$ & 1.880 & 4 & 0.351 & 6 \\
\hline $12-\mathrm{S} .113$ & 1.966 & 4 & 1.617 & 3 & 74.704 & 3 & 2.902 & $\begin{array}{l}1 \\
2 \\
\end{array}$ & 0.348 & 7 \\
\hline 13- S.116 & 1.806 & 8 & 1.294 & $\begin{array}{l}1 \\
2 \\
\end{array}$ & 41.894 & $\begin{array}{l}1 \\
4 \\
\end{array}$ & 1.408 & 1 & 0.510 & 3 \\
\hline $14-\mathrm{S} .45 / 29$ & 1.719 & $\begin{array}{l}1 \\
0\end{array}$ & 1.394 & 8 & 68.921 & 6 & 2.731 & $\begin{array}{l}1 \\
0\end{array}$ & 0.322 & 12 \\
\hline General men & 1.830 & & 1.437 & & 62.459 & & 2.499 & & 0.393 & \\
\hline $\operatorname{LSD}_{0.05}$ & 0.211 & & 0.183 & & 2.260 & & 0.451 & & 0.237 & \\
\hline C.V. \% & 2.99 & & 2.20 & & 9.39 & & 9.30 & & 16.09 & \\
\hline
\end{tabular}

Table 5. Phenotypic (rp) and genotypic (rg) correlation coefficients among seven 14 kenaf genotypes averaged over three successive seasons.

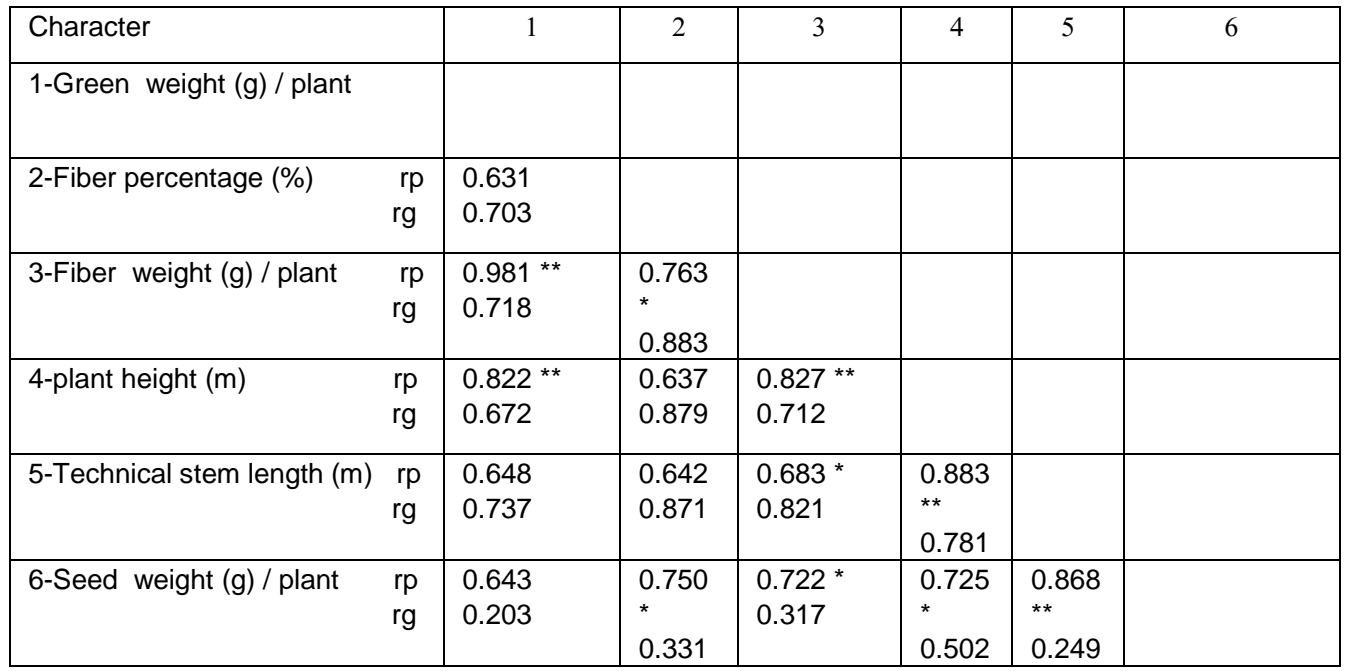

$*, * *=$ Indicate significance at the 0.05 and 0.01 levels of probability, respectively. 


\section{REFERENCES}

1. Abd El-Dayem, M. A. 2001. Evaluation of some kenaf genotypes under sandy soil and sprinkler irrigation. Annals of Agric. Sc. Moshtohor. 39: 847-856.

2. Abo-Kaied, H.M.H. 2007. Combining ability and gene action for yield and yield components in kenaf (Hibiscus cannabinus L.). Egypt. J. Agric. Res., 85(2): 535549.

3. Abo-Kaied H.M.H. and T.A. Abuo Zaid 2008. Estimation of some genetic parameters for yield and yield components in kenaf (Hibiscus cannabinus L.). Egypt. J. Agric. Res., 86(2): 585-595.

4. Bunpromma, K. 1992. Improvement of kenaf production in Northeast Thailand. Khonkaen-Agric.J. 20(6): 311-317.

5. Burton 1952. Quantitative inheritance in grasses. Proc. $6^{\text {th }}$ inter. Grassland. Confr., 1: 277-283.

6. El-Kady, E.A.F and Amna El-Sweify1995. Evaluation of some kenaf genotypes in relation to yield components and chemical composition of seeds. Egypt. J. Appl. Sci 10(6): 297-305.

7. El-Shimy, G.H., S.M. Gaafar and A.M. Hella 1990. Morphological and anatomical studies in some kenaf cultivars. Egypt. J. Appl. Sci. 5(7): 585-600.

8. Gomez, K.A. and A.A. Gomez 1984. Statistical Procedures for Agricultural Research. $2^{\text {nd }}$ Ed., John Wiley and Sons, NY. USA.

9. Johnson, H.W., H.F.Robinson, and R.E. Comstock 1955. Estimates of genetic and environmental variability in soybeans. Agron.J.47: 314-318.

10. Miller, P.A. and J.D. Rowling 1967. Selection for increased lint yield and correlated responses in upland cotton. Crop Sci. 7: 637-640

11. Mourad, N.K.M., A. I. Sahsah. and G.H. El-Shimy 1987. Studies on correlation and path coefficient analysis of components of fiber and seed yield in kenaf (Hibiscus cannabinus L.). Minufiya J. Agric. Res. 12: 89-104.

12. Osman, R. and A. Momtaz 1982. A comparative study of oil content, fatty acid composition and agronomic characters of five kenaf cultivars. Agric Res. Rev. 60(8). 127-139.

13. Subramanyam,D.,P.V. Rama Kumar, B. Krishnamurthy and S.Ismia 1995. Heritability and correlation studies in kenaf. Indian J.Genet., 55 (3):279-282. 


\section{التباين والتباين المشترك للصفات الزراعية في 14 تركيب وراثي من التيل}

\section{عفاف السيد عبد الواحد زهانة أماني محمد محي الدين الرفاعي}

$$
\text { معهُ بحوث المحاصيل الحقلية - مركز البحوث الزراعية - الجيزة - مصر }
$$

$$
\text { استخدمت في هذه الدر اسة } 14 \text { نركييا ور اثيا من التيل تم تقييمها خلال ثلاثة مو اسم }
$$

(2009،2010،2011) متتالية بمحطة البحوث الزر اعية بالإسماعيلية ، محافظة الإسماعيلية . وكان

التصميم التجريبي المستخدم هو القطاعات كاملة العشوائية ذات الثلاثة مكررات.

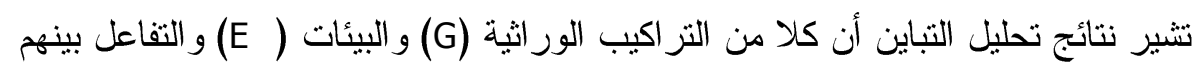

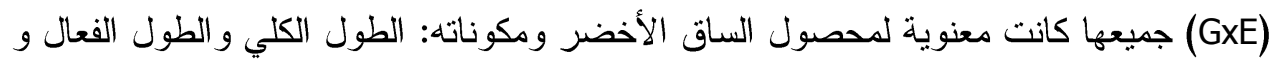

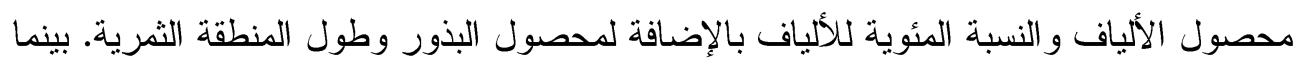

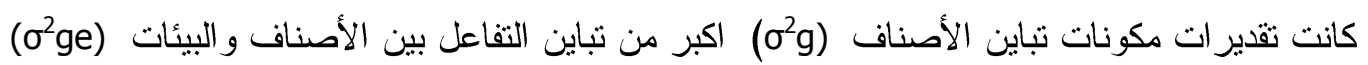
لكل الصفات المدروسة ماعدا محصول الألياف للفدان. ذلك يدل علي أن معظم التباين لهذه الصفات

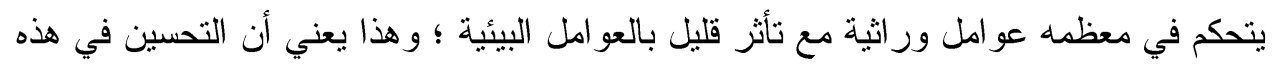

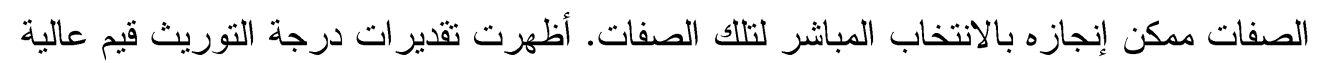
مقرون بذلك الفارق المنخفض بين معاملي التباين الظاهرب و الور اثي لصفة وزن البذور للنبات وكذلك لصفتي الطول الكلي و الطول الفعال. لذلك يمكن استخدام هذه الصفات كدلاثل انتخابية لتحسين صفئ الوزن الأخضر للساق مع إعطاء أهمية اكبر لصفتي الطول الكلي و الطول الفعال لتحسين صفة الوزن الأخضر للنبات.

كما اشارت النتائج إلى أن السلالتين ( 2/105، 20/96) كانتا متفوقتنين (مركز أول و ثاني في الترتيب) في معظم الصفات تحت الدراسة. بينما تفوقت السلالة 20/96 عن باقي السلالات في صفة محصول البذور للفدان كذلك السلالة 116 لصفة وزن البذور للنبات و السلالة 8 لصفة بنة

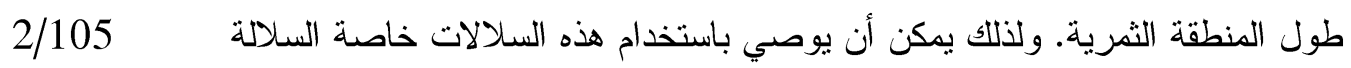
كأصناف تجارية للإنتاج كما يمكن استخدامها في برنامج التربية لإنتاج سلالات عالية المحصول. بلأل

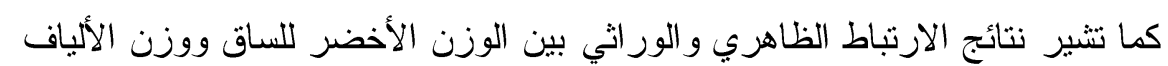

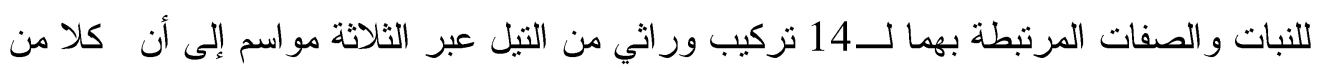
الطول الكلي و الطول الفعال يعتبران المكونين الرئيسين لصفة الوزن الأخضر للساق ، لذانئ لذلك يمكن

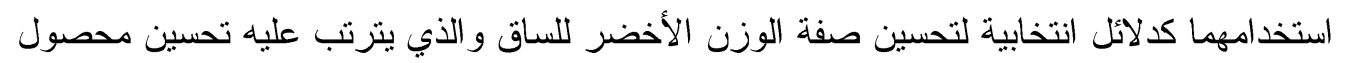

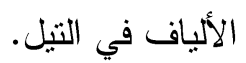

